Article

\title{
Does Work-Life Balance Moderate the Relationship between Career Commitment and Career Success? Evidence from an Emerging Asian Economy
}

\author{
Usama Najam ${ }^{1}$, Umar Burki ${ }^{2, *}$ and Wajiha Khalid ${ }^{3}$ \\ 1 Faculty of Business and Accountancy, University of Malaya, Kuala Lampur 50603, Malaysia; \\ usama@aumc.edu.pk \\ 2 Department of Business, History and Social Sciences, University of South-Eastern \\ Norway, 3603 Kongsberg, Norway \\ 3 Department of Business Administration, Air University Multan Campus, Multan, Punjab 60000, Pakistan; \\ Wajihakhalid50@hotmail.com \\ * Correspondence: Umar.Burki@usn.no
}

Received: 24 August 2020; Accepted: 30 September 2020; Published: 14 October 2020

\begin{abstract}
This study examines the relationship between career commitment and employee career success (objective and subjective success) in middle-level employees working in the service sector. Further, the study investigates the moderating effect of work-life balance on the relationship between career commitment and career success. By analyzing data from 360 middle level working employees, our empirical results show that career commitment has a positive and significant effect on the objective and subjective career success of employees. Work-life balance positively moderates the relationship between career commitment and subjective career success, whereas it fails to moderate the relationship between career commitment and objective career success. The study contributes by providing a better understanding of the employee's perception of career commitment and career success and their management in emerging markets. Avenues for future research are identified.
\end{abstract}

Keywords: career commitment; career success; work-life balance; Asia; emerging economy

\section{Introduction}

Researchers argue that personnel career success and career commitment is vital for organizations and individual's growth (Sullivan and Baruch 2009; Feldman and Ng 2007; Ng et al. 2005). Management literature (Burke 2006; Yean and Yahya 2013; Spurk et al. 2019) shows more focus on different appreciative types of job-related practices in organizations that enhance employees' career success. Similarly, organizational policies such as human resource practices play a vital role in an employee's career success (Kumar and Rajendran 2018). Literature accentuates that career enhancement effects organizational strategies such as frequent organizational shifts and networking bring about career success (de Janasz and Forret 2008). Current research argues that career success is embedded in a social environment and includes an employee's personal life and job-related factors. Therefore, it is essential to avoid examining career success in isolation (e.g., Ocampo et al. 2018).

Previous research (e.g., Seierstad and Kirton 2015) indicates a positive relationship between career commitment and career success. Career commitment (CC) as an antecedent for career success Carson and Bedeian (1994) demonstrates that career commitment is an employee's motivation toward a chosen job. Alnıaçik et al. (2012) defined career commitment as an employee's behavior to accept a job responsibility, seek new experience, and work settings to accomplish career goals. Research (Ballout 2009; Srikanth and Israel 2012) defines career success as an individual success is in his/her career and comprises of subjective career success factors (e.g., satisfaction, growth, etc.) and 
objective career success (e.g., salary level, promotion, etc.). Objective career success comprises concrete results, for example pay and advancement and appreciation in the work environment (Judge et al. 1995). In comparison, subjective career success refers to a person's personal view of success and reflected by occupational achievement, fulfillment with one's job, and vocational training (Judge et al. 1995; Aryee et al. 1994).

Work-life balance (WLB) is a person-centered approach, and each person has a unique work-life balance approach (Kossek et al. 2014). According to each person's career and life stage, it varies because of individual values, goals, and aspirations (Greenhaus and Allen 2011). Work-life balance is also referred to as a relationship between job times or space of work with additional life-related factors (Felstead et al. 2002). Literature also shows that in the presence of self-efficacy, individuals having high levels of career commitment achieve better career success (Ballout 2009).

When organizations provide a decent work-life balance, employees achieve better career success (Haar et al. 2014). Management literature (Haar et al. 2014; Kossek et al. 2014) refers to the work-life balance as an individual's ability to properly balance one's life roles. The work-life balance effects individual work outcomes, perceptions, and beliefs that may affect employees' career attitudes (Lyness and Judiesch 2014; Kossek et al. 2014). Similarly, it affects the career success of individuals. Career success demands an individual employee to devote and manage their work-life in a more self-directed manner (Lee et al. 2016; Mas-Machuca et al. 2016). It is vital to examine the social contexts in measuring career success factors related to employee work-life balance (Ferreira et al. 2020). Similarly, the associations between career commitment, career success, and work-life balance are likely to have different meanings in emerging Asia economies.

Prior research endorses a positive relationship between career commitment and career success (Carson et al. 1999; Day and Allen 2004). However, these studies only measure career commitment to subjective career success and completely ignore objective evaluation. Furthermore, research on subjective career evaluation fails to incorporate social norms of career success, such as individual salary or promotional history (Dries et al. 2009). It is essential to measure parallel how career success subjectively and objectively is affected by employees' career commitment for a better holistic view. Hence, this study intends to fill this research gap by measuring career commitment's impact on career success by incorporating both subjective and objective career success dimensions. Another vital gap in the career success literature is the absence of the boundary constraint condition. Relevant literature underscores that work-life balance significantly affects the employees' career success (Lyness and Judiesch 2008; Sturges and Guest 2004). This study fills this research gap by examining the moderating effect of work-life on the relationship between career commitment and career success (objective and subjective success).

This study focuses on the role of career commitment and work-life balance on an employee's career success in the middle-management levels. There is a lack of literature on how employees' work-family balance interacts with other predictors of career success (Ocampo et al. 2018), which is the main research question of this study. The authors attempt to contribute to this research gap. Further, they investigate the moderating role of work-life balance on the relationship between career commitment and career success.

In terms of contributes, this study augments in several ways. First, the study's research context is an emerging Asian economy, which provides a better insight into work-related and other social factors affecting career success. Further, organizational management styles, work environment culture, and the relation between work and family have different meanings in Asian societies regarding career success (Thornton and Fricke 1987). Second, our study's results would show whether Western management theories maintain their validity in an Asian management setting. Hence, this study follows Cooke (2018) argument about exploring the role of other factors that may affect human resource theoretical models and their outcomes. Third, the authors do not know other studies that examined the moderating role of work-life balance on the relationship between career commitment and career success. Hence, 
this paper examines the moderating role of work-life balance on the twin dimension of career success (subjective career success and objective career success).

The remainder of the paper is as follows. The next section describes the conceptual model and the formulated hypotheses. Next, we explain the empirical setting, data collection techniques, and validity of the measures, and the empirical results. The paper concludes with a discussion, research limitations, and directions for future research.

\section{Conceptual Model and Hypotheses}

Career commitment and work-life balance play a vital role in developing firms' human resource practices. Career commitment demands a strong sense of identification, active involvement, development, and persuasion in career goals (Srikanth and Israel 2012). Career commitment allows individuals to assess one's motivation and make an action to pursue their career. Existing researchers (Vandenberghe and Basak 2013; Crompton and Lyonette 2006) examine the role of career commitment and work-life balance on career success in the Western context. Furthermore, a bit of research examined the role of career commitment and work-life balance on career success in the Asian context. Ballout (2009) showed that self-efficacy moderates the relationship between career commitment and career success. Our model identifies that individuals must commit to their careers, because it will lead them toward their career success and provide a balance between their work and life helps to strengthen or weaken this relationship. Figure 1 illustrates our research model.

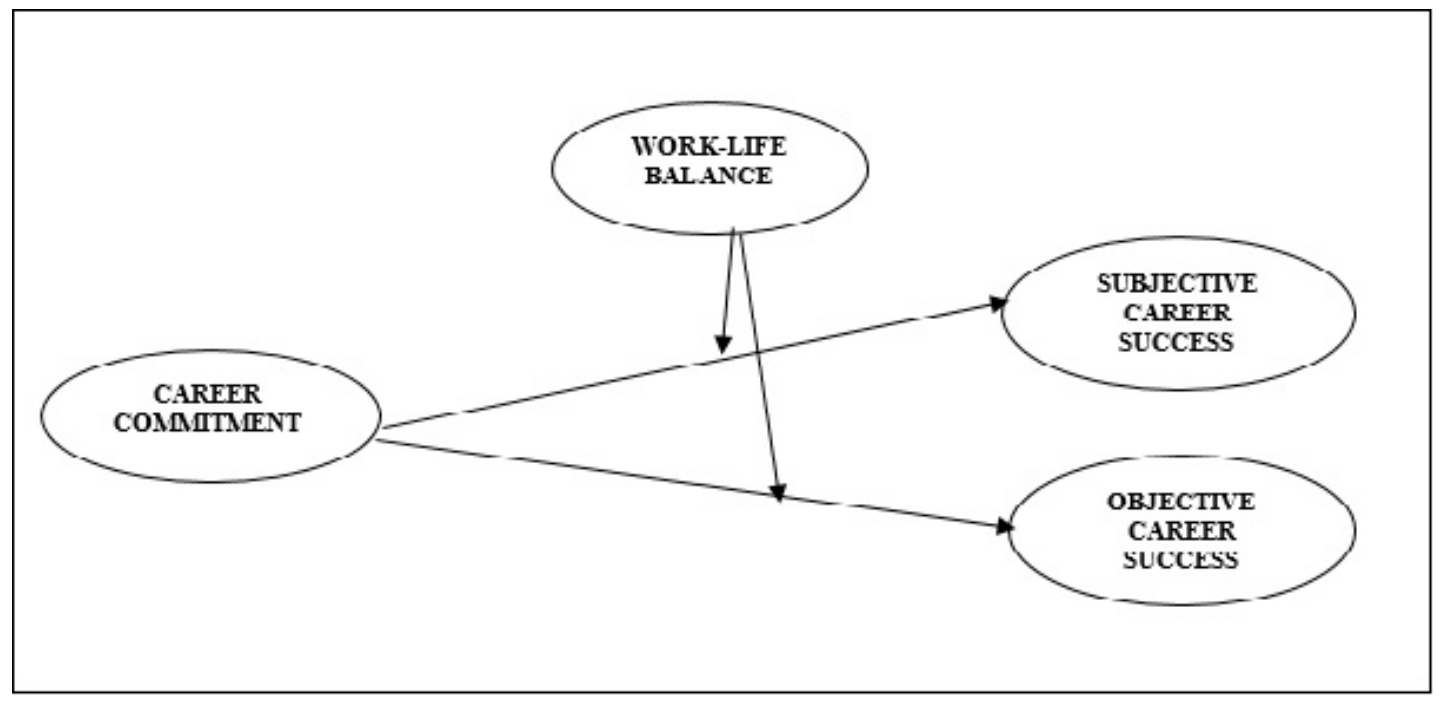

Figure 1. Research model.

\subsection{Career Commitment and Career Success}

Career success is an essential variable in career research. It is an individual's career experience (Arthur et al. 2005). Arthur et al. (2005) defined career success as a work-related outcome desired by an individual that they accomplished during work experience over time. Career success is also defined as a person's preference and capability to attain positive degree work and outcomes for their career (Verbruggen 2012). Career scholars (e.g., Judge et al. 1995; Verbruggen 2012) agreed that career success is comprised of both a subjective and an objective side. Subjective career success refers to an individual's perception of a career. Mostly, it operationalized growth or recognition in job or career satisfaction (Heslin 2005). Objective career success comprises of the concrete or tangible result; for instance, a pay rise, promotions, and advancement (Dries et al. 2009). Therefore, individuals and organizations need to understand their success' subjective and objective goals and their effects.

Prior research supports the relationship of a career commitment to career success. For instance, Sultana et al. (2016) indicate that employees' commitment to their careers plays a crucial role in their 
career success because employees can control their careers. Srikanth and Israel (2012) shows that career commitment predicts career success because commitment leads individuals toward favorable career outcomes. Alnıaçı et al. (2012) show that career motivation has a positive correlation with job satisfaction. Ballout (2009) indicates that career commitment is positively associated with career success. Employees who show better career commitment achieve more career success. Hence, we propose:

Hypothesis 1 (H1): Career commitment has a positive effect on subjective career success.

Hypothesis 2a (H2a): Career commitment has a positive effect on objective career success (promotions).

Hypothesis $\mathbf{2 b}$ (H2b): Career commitment has a positive effect on objective career success (salary).

\subsection{The Moderating Role of Work-Life Balance}

Individual behavioral attitudes depend on the human's ability to manage their life because individuals change their attitudes consistent with the work and life environment (Barnett and Hyde 2001). We argue that work-life balance is central in affecting the relationship between career commitment and career attitudes. Research (Kossek et al. 2014) finds that many employees valued work-life balance in their lives, which affects individual perceptions and beliefs about personal career attitudes. Better living and career goals balance motivate employees toward more job commitment (Poulose and Sudarsan 2014).

The literature on commitment and career success reports mixed results. For instance, studies (Maeran et al. 2013; Adams et al. 1996) found a negative relationship between work-life balance and job satisfaction. Other research studies (Shujaat et al. 2013) report a positive relationship between work and non-work balance regarding employee career and job satisfaction. Malik et al. (2010) findings suggest an insignificant effect between work-life balance and job satisfaction. Such opposing results show that work-life balance affects an employee's behavior towards career success. Inconclusive results underline the need to examine the moderation effect of work-life balance and its impact on career success.

When employees demonstrate a commitment to their career, this commitment will help them achieve subjective career success (Barnett and Hyde 2001). This balance is vital for individuals' subjective career success (Gálvez et al. 2020). Employees who have high work-life balance have firm control over work, life, and less conflict (Delecta 2011). In contrast, employees with a low balance between work and family showed dissatisfaction at work and diminishing family involvement (Delecta 2011). In the presence of high work-life balance, employees seek career success in subjective and objective areas. Hence, we propose:

Hypothesis 3 (H3): Work-life balance positively moderates the relationship between career commitment and subjective career success.

Hypothesis 4a (H4a): Work-life balance positively moderates the relationship between career commitment and objective career success (promotions).

Hypothesis $4 \mathbf{b}$ (H4b): Work-life balance positively moderates the relationship between career commitment and objective career success (salary rises).

\section{Methodology and Measurement}

To test our proposed model, we applied a qualitative approach to test the effect of career commitment on career success and test the moderating effect of work-life balance. Therefore, to test our theoretical model empirically, we selected middle-management employees working in Pakistan's service sector. We applied a cross-sectional survey method to collect the data and sent the self-administered questionnaires to the target respondents. We collected data (1) by visiting the organizations, (2) mailing the questionnaire, and (3) by courier. The respondents (managers and executives) worked in the 
service sector firms, mainly in telecommunication firms, IT firms, and the banking sector. The key respondents worked as managers and business executives, and the selected firms offer working individuals numerous opportunities to excel in their careers. The respondents had master's degrees in their respective fields, were well conversant with the research problem, and had a good command of English. We visited the selected companies to ensure that they meet the selection criteria. We distributed four hundred and twenty (420) questionnaires to diverse middle-management persons working in the service sector. During the data collection process, we applied personal connections to achieve the maximum number of respondents. In the end, we selected received three hindered and sixty (360) useable responses, providing us an excellent response rate of $85 \%$.

A cover letter stated the academic purpose of research to examine the employee's career success achieved through career commitment and balancing their life with work. We applied a five-point Likert scale to measure all the items of our constructs. We took measures to counter the potential issues related to common method bias. First, we used the procedural remedies to control the variance by assuring the respondents about the study's confidentiality and anonymity to the minimum respondent's bias (Chang et al. 2010). Second, we used the statistical remedies by conducting a common latent factor test to impute the means after extracting the unexplained variance on a single latent factor using Amos. Since all the measures were self-reported, there has been a chance of common method bias. The composite variables were extracted by incorporating the unexplained variance explained by the common latent factor to deal with the common method bias (see Table 1).

Table 1. Respondents profiles.

\begin{tabular}{cc}
\hline Characteristics & Percentage \\
\hline Industry & \\
Telecommunication & 24.4 \\
Banks & 62 \\
IT & 13.6 \\
Total & 100 \\
\hline Gender & \\
Male & 74.4 \\
Female & 25.6 \\
Total & 100 \\
\hline Work Experience & \\
0 to 3 years & 33.6 \\
4 to 9 years & 45.8 \\
9 to 12 years & 20.6 \\
Total & 100 \\
\hline Marital Status & \\
Single & 46.8 \\
Married & 49.5 \\
Others & 3.7 \\
Total & 100 \\
\hline
\end{tabular}

\subsection{Measures and Control Variables}

This study modified the existing scales to measure the dependent, independent, and control variables. Career commitment (CC) measures individual feelings towards one's job. We selected four items from Blau (1989). Work-life balance refers to the balance of managing work and non-work life effectively. We selected five items from Gröpel and Kuhl (2009). Career success is measured by subjective success and objective success. For subjective career success (SCS), we used the sixteen items developed by Shockley et al. (2016). These items measure the level of recognition, quality work satisfaction, growth, and development that individuals achieved during their careers. Objective career success is measured by using two proxies, salary level and promotion (Heslev 2005). The salary level 
reflects the increase in the respondent's salary overtime in career. In contrast, the promotion level indicates the level of promotion that an individual received during their career.

We incorporated work experience, marital status, and gender as control variables in our theoretical model. Work experience represents the number of years an individual has been working in a job and reflects the level of commitment and motivation towards the job and its impact on an individual's career success. We integrated a natural logarithm of the number of years doing a job in an organization to account for this effect. Marital status and gender are the two dummy variables. Marital status identifies whether a respondent is married or single. This control variable measures the impact of an individual's marital status on career success. Similarly, gender reflects the number of male and female employees working in the service sector ( $\mathrm{Ng}$ et al. 2005).

\subsection{Validation of Construct}

We checked the convergent validity of multi-item constructs (CC, SCS, WLB). First, we performed an exploratory factor analysis (EFA). Each measurement item loaded on their respective constructs (between 0.50-0.90), providing convergent validity for the theoretical model. Cronbach's alpha for all the constructs ranged from 0.681 to 0.819 , indicating suitable reliability for measurement scales (Nunnally and I. 1994). We applied AMOS 22 to verify the internal consistency and reliability of the measurement model. Our confirmatory factor analysis (CFA) test showed satisfactory fit indices for our data. The $X^{2} / \mathrm{df}$ (Chi square/degree of freedom ratio) $=1.91$, and other fit indices $(\mathrm{CFI}=0.923$, IFI $=0.924$, TLI $=0.910$, RMSEA (Root mean square error of approximation) $=0.050$, and PCLOSE (Probability of close fit and should be insignificant $>0.05)=0.454$ ) values provided an acceptable fit (Hu and Bentler 1999) for our model. Table 2 provides the information regarding respective constructs, their items, and their Cronbach's alpha value. Table 3 shows the correlation matrix of the model.

Table 2. Description of items and validity measures.

\begin{tabular}{|c|c|}
\hline Constructs & $\begin{array}{l}\text { Responded on a 5-Point Likert Scale Where } 1 \text { Indicated Strongly Disagrees and } 5 \\
\text { Indicated Strongly Agree. }\end{array}$ \\
\hline $\begin{array}{l}\text { Subjective Career Success (SCS) } \\
12 \text { items, } \alpha=0.819\end{array}$ & $\begin{array}{l}\text { SCS1: "My supervisors have told me I do a good job." } \\
\text { SCS2: "Organizations I worked for have recognized me as a good performer." } \\
\text { SCS3: "I have been recognized for my contributions." } \\
\text { SCS4: "I am proud of the quality of the work I have produced." } \\
\text { SCS5: "I have met the highest standards of quality in my work." } \\
\text { SCS7: "Decisions that I have made have impacted my organization." } \\
\text { SCS8: "The organizations I have worked for have considered my opinion regarding important } \\
\text { issues." } \\
\text { SCS9: "Others have taken my advice into account when making important decisions." } \\
\text { SCS10: "I have chosen my own career path." } \\
\text { SCS13: "I have continuously improved by developing my skill set." } \\
\text { SCS14: "My career is personally satisfying." } \\
\text { SCS16: "I have found my career quite interesting." }\end{array}$ \\
\hline $\begin{array}{l}\text { Work-Life Balance (WLB) } \\
05 \text { items, } \alpha=0.681\end{array}$ & $\begin{array}{l}\text { WLB1: "Because of my work, I have no free time" } \\
\text { WLB2: "Because of my work, I neglect my family" } \\
\text { WLB3: "Because of my work, I neglect my friends" } \\
\text { WLB4: "I have enough time for my friends." } \\
\text { WLB5: "I have enough time for my family (partner, parents, children)," }\end{array}$ \\
\hline $\begin{array}{l}\text { Career Commitment }(\mathrm{CC}) \\
04 \text { items, } \alpha=0.788\end{array}$ & $\begin{array}{l}\text { CC2: "I want a career in this job." } \\
\text { CC4: "If I had all the money I needed, I would still want to be in this job." } \\
\text { CC5: "I do not want to leave my job as I enjoy doing it." } \\
\text { CC6: "This is my ideal job for my life work." }\end{array}$ \\
\hline $\begin{array}{l}\text { Objective Career success } \\
\text { ITEMS NAME }\end{array}$ & $\begin{array}{l}\text { We measure objective career success through the absolute value (number of promotions and a } \\
\text { salary increase). Respondents reported the number of times they received a promotion, and } \\
\text { the difference between the starting salary and current salary showed the salary increase. }\end{array}$ \\
\hline Work Experience 1 item & A natural logarithm of the number of years an individual is doing a job in an organization. \\
\hline Marital Status 1 item & $\begin{array}{l}\text { The number of employees who are where unmarried coded as } 1 \text {, married coded as } 2 \text {, and } \\
\text { others coded as } 3 \text {. }\end{array}$ \\
\hline Gender 1 item & dummy variable, where males were coded as 1 , and females coded as 2 . \\
\hline
\end{tabular}


Table 3. Correlation matrix.

\begin{tabular}{ccccccccc}
\hline & SCS & OCS1 & OCS2 & WLB & CC & LogW & M & G \\
\hline SCS & 1 & & & & & & & \\
OCS1 & 0.019 & 1 & & & & & & \\
OCS2 & $0.144^{* *}$ & $0.147^{* *}$ & 1 & & & & & \\
WLB & $0.209^{* *}$ & -0.015 & $-0.131^{*}$ & 1 & & & & \\
CC & $0.421^{* *}$ & 0.090 & $0.135^{*}$ & $0.142^{* *}$ & 1 & & & \\
LogW & 0.053 & $0.513^{* *}$ & $0.193^{* *}$ & $-0.112^{*}$ & 0.086 & 1 & & \\
M & -0.009 & $0.199^{* *}$ & 0.092 & 0.017 & 0.41 & $0.405^{* *}$ & 1 & \\
G & $-0.149^{* *}$ & -0.074 & $-0.135^{*}$ & -0.035 & -0.069 & $-0.145^{* *}$ & -0.051 & 1 \\
Mean & 2.47 & 2.11 & 62.11 & 1.43 & 2.63 & 2.34 & 1.57 & 1.25 \\
SD & 0.332 & 1.53 & 72.84 & 0.302 & 0.612 & 1.30 & 0.583 & 0.436 \\
N & 360 & 360 & 360 & 360 & 360 & 360 & 360 & 360 \\
\hline
\end{tabular}

Note: OCS1 = objective career success 1, OCS2 = Objective career success 2, M = Martial Status, G = Gender ${ }^{* *} p<0.01,{ }^{*} p<0.05$.

\section{Empirical Analysis and Results}

\subsection{Structural Equation Modeling}

By using AMOS 22, we test the proposed hypotheses. The results revealed a satisfactory structural equation model fit, as indicated by the ratio (CMIN/DF $=3.1)$ and the fit indices $(\mathrm{CFI}=0.912, \mathrm{IFI}=0.924$, $\mathrm{TLI}=0.559$, and RMSEA $=0.055$ ). The results provide support for the hypotheses $\mathrm{H} 1, \mathrm{H} 2 \mathrm{a}, \mathrm{and} \mathrm{H} 2 \mathrm{~b}$. Career commitment is positively related to subjective career success $(\beta=0.388, p<0.001)$, number of promotions $(\beta=0.157, p<0.05)$, and salary level $(\beta=0.154, p<0.01)$.

\subsection{Moderation Analysis}

To test for interaction effects, we centered and introduced interaction terms into our model. The work-life balance had a significant but negative moderating effect on the relationship between career commitment and subjective career success $(b=-0124, \mathrm{p}<0.001)$, supporting $\mathrm{H}_{3}$, while it had no significant moderating effect on the relationship between career commitment and objective career success, lending no support to both $\mathrm{H}_{4 \mathrm{a}}$ and $\mathrm{H}_{4 \mathrm{~b}}$.

Figures 2 and 3 show significant interaction. These graphs show that in the presence of low WLB, career commitment among employees leads toward low subjective career success. In contrast, high career commitment among employees will result in high subjective career success. While in the presence of high work-life balance, low career commitment will result in more career success, and high commitment toward career will result in higher subjective career success. The graph also shows that the lines get intercepts after some time, and the results become reverse. In this case, high work-life balance and high commitment towards a career will result in low subjective career success. If employees want to enjoy career success, then their work-life balance gets affected (see Table 4).

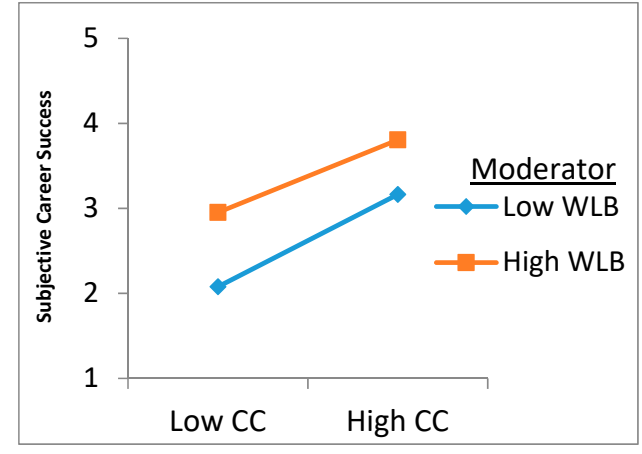

Figure 2. The moderation effect I. 


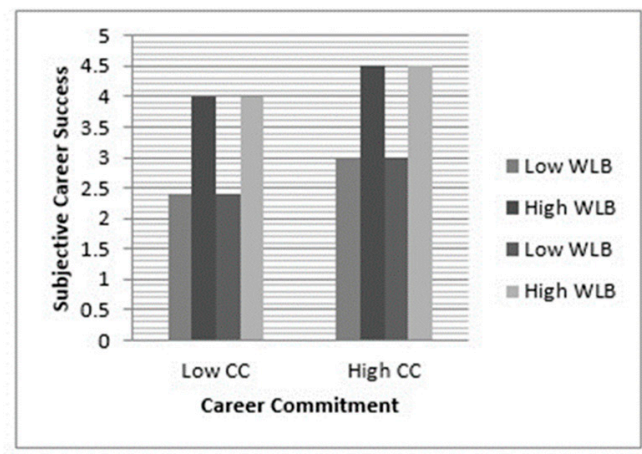

Figure 3. The moderation effect II.

Table 4. Moderation analysis result.

\begin{tabular}{cccc}
\hline Variables & Dependent Variables & \\
\hline & $\begin{array}{c}\text { Subjective Career } \\
\text { Success }\end{array}$ & $\begin{array}{c}\text { Objective Career } \\
\text { Success (Promotions) }\end{array}$ & $\begin{array}{c}\text { Objective Career } \\
\text { Success (Salary) }\end{array}$ \\
\hline $\begin{array}{c}\text { Control Variables } \\
\text { Gender }\end{array}$ & $-0.186(.065)^{* * *}$ & $-0.259(.185)$ & $-22.54(8.7)$ \\
Marital Status & $-0.009(0.49)$ & $0.524(0.136)^{* * *}$ & $11.466(6.57)^{* *}$ \\
\hline $\begin{array}{c}\text { Independent Variables } \\
\text { Career Commitment } \\
\text { Moderator }\end{array}$ & $0.388(0.028)^{* * *}$ & $0.157(0.095)^{* *}$ & $0.154^{*}$ \\
Work-Life Balance & $0.142(0.031)^{* * *}$ & $-0.029(0.99)$ & $-0.155^{* * *}$ \\
CC WLB & $-0.124(0.020)^{* * *}$ & $0.003(0.65)$ & $-0.030(0.39)$ \\
\hline & $* * * p<0.001, * * p<0.05)^{*} p<0.01$. &
\end{tabular}

\section{Discussion and Conclusions}

This research's main objective was to find out the relation of career commitment on career success, including both dimensions, subjective career success and objective career success, in the service sector of Pakistan. With that, we also examine the moderating role of work-life balance in the hypothesized direct relationships (see Table 5).

Table 5. Hypothesis result.

\begin{tabular}{ll}
\hline Hypothesis & Results \\
\hline $\mathrm{H}_{1}:$ Career commitment has a positive effect impact on subjective career success. & Supported \\
$\mathrm{H}_{2 \mathrm{a}}$ : Career commitment has a positive effect on objective career success (promotions). & $\begin{array}{l}\text { Supported } \\
\mathrm{H}_{2 \mathrm{~b}} \text { : Career commitment has a positive effect on objective career success (salary) }\end{array}$ \\
$\mathrm{H}_{3}$ : Work-life balance positively moderates the relationship between career commitment & Supported \\
$\begin{array}{l}\text { and subjective career success. } \\
\mathrm{H}_{4 \mathrm{a}} \text { : Work-life balance positively moderates the relationship between career commitment } \\
\text { and objective career success (promotions). }\end{array}$ & No support \\
$\mathrm{H}_{4 \mathrm{~b}}$ : Work-life balance positively moderates the relationship between career commitment \\
and objective career success (salary). & No support \\
\hline
\end{tabular}

Our results support that career commitment positively affects subjective and objective career successes (i.e., promotion and salary). The findings are consistent with previous studies (Ballout 2009; Colakoglu 2011; Sultana et al. 2016) and augment the logic that career commitment brings positive extrinsic and intrinsic outcomes for employees.

The role of work-life balance as a moderator positively moderates the relationship between career commitment and subjective career success (subjective as well as objective career success). The hypothesis was accepted in case of subjective career success. Therefore, work-life balance 
moderates the relationship between career commitment and subjective career success in such a way that at a low level of work-life balance, there is low impact of career commitment on career success. However, as work-life balance increases, the impact from career commitment to career success increases to a point afterward; a very high level of career commitment would not increase the career success any further instead, try to dampen it (see Figure 2).

Our results are consistent with previous studies (Amin et al. 2016; Lyness and Judiesch 2008; Qu and Zhao 2012; Yadav and Dabhade 2014). The hypothesis (H3) is supported under the role theory approach (Adams et al. 1996), which underlines that at some levels, a high balance between work and life will decrease the success level among employees. In the case of objective career success ( $\mathrm{H} 4 \mathrm{a}$ and $\mathrm{H} 4 \mathrm{~b}$ ), we found out an insignificant relationship of work-life balance between career commitment and objective career success. The primary reason for the negligible moderation effect of WLB on objective career success (salary and promotion) could be due to Pakistan's job compensation system. Pakistan's compensation system is based on seniority rather than performance. In Pakistan, the objective measure for career success (salary and promotion) is not much affected by employee performance instead of the employee's experience and years of work.

This study provides implications for individuals as well as organizations. The findings suggest that individual behavior toward career commitment yields results in the form of subjective career success such as satisfaction, recognition, etc., and for objective career success such as promotions and salary raise. Such career commitment will also beneficial for employees with high work-life balance. Regarding objective career success, career commitment will not have a better pay off effect in the presence of work-life balance. Our finding suggests that when organizations motivate their employees to become more committed in their respective positions, it positively affects the organization's performance and the improvement of an individual's subjective and objective career success. Hence, organizations are responsible for creating environments where employees feel motivated and committed toward their job, which generates a win-win outcome for all (Vandenberghe and Basak 2013). If an organization wants its employees to achieve subjective and objective career success, they should develop a deep understanding of factors that affect career commitment.

\section{Limitations, Implications, and Future Recommendation}

Like other research studies, this study has limitations. Our analysis focuses on examining the role of a career commitment to achieving a high career success level. Individual measure their career success with other factors such as organization performance, organization status (national vs. international), etc. Our study followed a quantitative research method and used a self-reporting survey questionnaire for collecting data from the service sector employees. Self-reported questionnaire structure results are typically biased. Hence, future research should overcome this limitation by using a multi-actor data approach. Future studies should collect data more comprehensively. Selecting a single sector from individual country limits in interpreting and generalizing the results. Career commitment and career success are crucial for practitioners. Future researchers should apply individual factors such as intelligence, personality, etc., as moderators to better understand the mediating effect in their relationship.

\section{Conclusions}

This study's goal has been to contribute to career success and work-life balance from the employees' perspective. We describe and measure the relationship between career commitment and career success practices. Our findings indicate that career commitment positively affects career success objectives, and work-life moderates some of the career success areas. In terms of contributions, our study examines objective and subjective career success concurrently as an outcome of career commitment in an emerging Asian economy. This study's findings also provide a better understanding of management practices regarding employees' career objectives and their commitment to the employer. 
Author Contributions: All the authors contributed equally in this research article regarding conceptualization, methodology, formal analysis, and writing the original draft of the manuscript. All authors have read and agreed to the published version of the manuscript.

Funding: This research received no external funding.

Conflicts of Interest: The authors declare no conflict of interest.

\section{References}

Adams, Gary A., Lynda A. King, and Daniel W. King. 1996. Relationships of job and family involvement, family social support, and work-family conflict with job and life satisfaction. Journal of Applied Psychology 81: 411. [CrossRef]

Alnıaçık, Ümit, Esra Alnıaçık, Kültigin Akçin, and Serhat Erat. 2012. Relationships Between Career Motivation, Affective Commitment and Job Satisfaction. Procedia-Social and Behavioral Sciences 58: 355-62. [CrossRef]

Amin, Saif Ul., Sultan Qurrat-Ul-Ain., Aftab Junaid, and Anjum Uzma. 2016. Different factors of Work Life Balance Affecting Employee Job Satisfaction: A Study of Banking Sector of Sargodha Region. Entrepreneurship and Innovation Management Journal 4: 231079.

Arthur, Michael B., Svetlana N. Khapova, and Celeste PM Wilderom. 2005. Career success in a boundaryless career world. Journal of Organizational Behavior 26: 177-202. [CrossRef]

Aryee, Samuel, Yue Wah Chay, and Juniper Chew. 1994. An investigation of the predictors and outcomes of career commitent in three career stages. Journal of Vocational Behavior. [CrossRef]

Ballout, Hassan I. 2009. Career commitment and career success: moderating role of self-efficacy. Career Development International 14: 655-70. [CrossRef]

Barnett, Rosalind Chait, and Janet Shibley Hyde. 2001. Women, men, work, and family: An expansionist theory. American Psychologist 56: 781. [CrossRef] [PubMed]

Blau, Gary. 1989. Testing the generalizability of a career commitment measure and its impact on employee turnover. Journal of Vocational Behavior 35: 88-103. [CrossRef]

Burke, Ronald. 2006. Why leaders fail: Exploring the darkside. International Journal of Manpower. [CrossRef]

Carson, Kerry D., and Arthur G. Bedeian. 1994. Career Commitment: Construction of a Measure and Examination of Its Psychometric Properties. Journal of Vocational Behavior. [CrossRef]

Carson, Kerry D., Paula Phillips Carson, C. William Roe, Betty J. Birkenmeier, and Joyce S. Phillips. 1999. Four commitment profiles and their relationships to empowerment, service recovery, and work attitudes. Public Personnel Management 28: 1-13. [CrossRef]

Chang, Sea-Jin, Arjen Van Witteloostuijn, and Lorraine Eden. 2010. From the Editors: Common method variance in international business research. Journal of International Business Studies 41: 178-184. [CrossRef]

Colakoglu, Sidika N. 2011. The impact of career boundarylessness on subjective career success: The role of career competencies, career autonomy, and career insecurity. Journal of Vocational Behavior 79: 47-59. [CrossRef]

Cooke, Fang Lee. 2018. Concepts, contexts, and mindsets: Putting human resource management research in perspectives. Human Resource Management Journal 28: 1-13. [CrossRef]

Crompton, Rosemary, and Clare Lyonette. 2006. Work-life "balance" in Europe. Acta Sociologica 49: $379-393$. [CrossRef]

Day, Rachel, and Tammy D. Allen. 2004. The relationship between career motivation and self-efficacy with protégé career success. Journal of Vocational Behavior 64: 72-91. [CrossRef]

de Janasz, Suzanne C., and Monica L. Forret. 2008. Learning the art of networking: A critical skill for enhancing social capital and career success. Journal of Management Education 32: 629-650. [CrossRef]

Delecta, P. 2011. Work Life Balance. International Journal of Current Research 3: 186-189.

Dries, Nicky, Roland Pepermans, Joeri Hofmans, and Laura Rypens. 2009. Development and validation of an objective intra-organizational career success measure for managers. Journal of Organizational Behavior 30: 543-560. [CrossRef]

Feldman, Daniel C., and Thomas W. H. Ng. 2007. Careers: Mobility, Embeddedness, and Success. Journal of Management 33: 350-77. [CrossRef]

Felstead, Alan, Nick Jewson, Annie Phizacklea, and Sally Walters. 2002. Opportunities to work at home in the context of work-life balance. Human Resource Management Journal 12: 54-76. [CrossRef] 
Ferreira, Pedro, Carla Gabriel, Sílvia Faria, Pedro Rodrigues, and Manuel Sousa Pereira. 2020. What if employees brought their life to work? The relation of life satisfaction and work engagement. Sustainability 12: 2743. [CrossRef]

Gálvez, Ana, Francisco Tirado, and M. Jesús Martínez. 2020. Work-Life Balance, Organizations and Social Sustainability: Analyzing Female Telework in Spain. Sustainability 12: 3567. [CrossRef]

Greenhaus, Jeffrey H., and Tammy D. Allen. 2011. Work-Family Balance: A Review and Extension of the Literature. Available online: https://psycnet.apa.org/record/2010-06010-009 (accessed on 11 October 2020).

Gröpel, Peter, and Julius Kuhl. 2009. Work-life balance and subjective well-being: The mediating role of need fulfilment. British Journal of Psychology 100: 365-75. [CrossRef] [PubMed]

Haar, Jarrod M., Marcello Russo, Albert Suñe, and Ariane Ollier-Malaterre. 2014. Outcomes of work-life balance on job satisfaction, life satisfaction and mental health: A study across seven cultures. Journal of Vocational Behavior 85: 361-73. [CrossRef]

Heslin, Peter A. 2005. Conceptualizing and evaluating career success. Journal of Organizational Behavior 26: 113-36. [CrossRef]

$\mathrm{Hu}$, Li-tze, and Peter M. Bentler. 1999. Cutoff criteria for Fit Indexes in Covariance Structure Analysis: Conventional Criteria versus New Alternatives. Structural Equation Modeling: A Multidisciplinary Journal 6: 1-55. [CrossRef]

Judge, Timothy A., Daniel M. Cable, John W. Boudreau, and Robert D. Bretz Jr. 1995. An Empirical-Investigation of the Predictors of Executive Career Success. Personnel Psychology 48: 485-519. [CrossRef]

Kossek, Ellen Ernst, Monique Valcour, and Pamela Lirio. 2014. The sustainable workforce: Organizational strategies for promoting work-life balance and wellbeing. Work and Wellbeing: A Complete Reference Guide III: 1-24. [CrossRef]

Kumar, J. Ramesh, and R. Rajendran. 2018. Impact of Education and Work Environment on Quality of Work Life in IT Sector. Available online: https://www.researchgate.net/profile/B_S_R_Murthy/publication/ 323956523_MSM_Enterprises_in_India_Roll_Of_Marketing_Services_To_Customer_Satisfaction/links/ 5b0250f64585154aeb0614d2/MSM-Enterprises-in-India-Roll-Of-Marketing-Services-To-CustomerSatisfaction.pdf\#page $=51$ (accessed on 11 October 2020).

Lee, Yunsoo, Kibum Kwon, Woocheol Kim, and Daeyeon Cho. 2016. Work Engagement and Career: Proposing Research Agendas Through a Review of Literature. Human Resource Development Review 15: 29-54. [CrossRef]

Lyness, Karen S., and Michael K. Judiesch. 2008. Can a manager have a life and a career? International and multisource perspectives on work-life balance and career advancement potential. The Journal of Applied Psychology 93: 789-805. [CrossRef] [PubMed]

Lyness, Karen S., and Michael K. Judiesch. 2014. Gender egalitarianism and work-life balance for managers: Multisource perspectives in 36 countries. Applied Psychology 63: 96-129. [CrossRef]

Maeran, Roberta, Francesco Pitarelli, and Francesco Cangiano. 2013. Work-life balance and job satisfaction among teachers. Interdisciplinary Journal of Family Studies 18: 1.

Malik, Muhammad Imran, Solomon Fernando Gomez, Mehboob Ahmad, and Muhammad Iqbal Saif. 2010. Examining the relationship of work-life balance, job satisfaction and turnover in Pakistan. OIDA International Journal of Sustainable Development 2: 27-33.

Mas-Machuca, Marta, Jasmina Berbegal-Mirabent, and Ines Alegre. 2016. Work-life balance and its relationship with organizational pride and job satisfaction. Journal of Managerial Psychology. [CrossRef]

Ng, Thomas W. H., Lillian T. Eby, Kelly L. Sorensen, and Daniel C. Feldman. 2005. Predictors of objective and subjective career success: A meta-analysis. Personnel Psychology 58: 367-408. [CrossRef]

Nunnally, Jum C., and Bernstein I. 1994. Psychometric Theory, 3rd ed. New York: McGraw-Hill.

Ocampo, Anna Carmella G., Simon Lloyd D. Restubog, Maria Emma Liwag, Lu Wang, and Claire Petelczyc. 2018. My spouse is my strength: Interactive effects of perceived organizational and spousal support in predicting career adaptability and career outcomes. Journal of Vocational Behavior 108: 165-77. [CrossRef]

Poulose, Shobitha, and N. Sudarsan. 2014. Work-Life Balance: A Conceptual Review. Journal of Advances in Management and Economics 3: 1-17. [CrossRef]

Qu, Hailin, and Xinyuan Roy Zhao. 2012. Employees' work-family conflict moderating life and job satisfaction. Journal of Business Research 65: 22-28. [CrossRef]

Seierstad, Cathrine, and Gill Kirton. 2015. Having It All? Women in High Commitment Careers and Work-Life Balance in Norway. Gender, Work and Organization 22: 390-404. [CrossRef] 
Shockley, K. M., H. Ureksoy, O. B. Rodopman, L. F. Poteat, and T. R. Dullaghan. 2016. Development of a new scale to measure subjective career success: A mixed-methods study. Journal of Organizational Behavior 37: 128-53. [CrossRef]

Shujaat, Sobia, Saira Sana, Faisal Aftab, and Ishtiaq Ahmed. 2013. Impact of Career Development on Employee Satisfaction in Private Banking Sector Karachi. Journal of Management and Social Sciences 9: 1-8.

Spurk, Daniel, Andreas Hirschi, and Nicky Dries. 2019. Antecedents and Outcomes of Objective Versus Subjective Career Success: Competing Perspectives and Future Directions. Journal of Management 45: 35-69. [CrossRef]

Srikanth, P. B., and D. Israel. 2012. Career Commitment and Career Success: Mediating Role of Career Satisfaction. The Indian Journal of Industrial Relations 48: 137-49.

Sturges, Jane, and David Guest. 2004. Working to live or living to work? Work/life balance early in the career. Human Resource Management Journal 14: 5-20. [CrossRef]

Sullivan, Sherry E., and Yehuda Baruch. 2009. Advances in career theory and research: A critical review and agenda for future exploration. Journal of Management 35: 1542-71. [CrossRef]

Sultana, Razia, Amna Yousaf, Iram Khan, and Abubakr Saeed. 2016. Probing the interactive effects of career commitment and emotional intelligence on perceived objective/subjective career success. Personnel Review 45: 724-42. [CrossRef]

Thornton, Arland, and Thomas E. Fricke. 1987. Social Change and the Family: Comparative Perspectives from the West, China, and South Asia. Sociological Forum 2: 746-79. [CrossRef]

Vandenberghe, Christian, and Afife Basak. 2013. Career commitment, proactive personality, and work outcomes: A cross-lagged study. Career Development International. [CrossRef]

Verbruggen, Marijke. 2012. Psychological mobility and career success in the "New" career climate. Journal of Vocational Behavior 81: 289-97. [CrossRef]

Yadav, Rajesh K., and Nishant Dabhade. 2014. Work Life Balance and Job Satisfaction among the Working Women of Banking and Education Sector-A Comparative Study. International Letters of Social and Humanistic Sciences 21: 181-201. [CrossRef]

Yean, Tan F., and Khulida K. Yahya. 2013. The Influence of Human Resource Management Practices and Career Strategy on Career Satisfaction of Insurance Agents. International Journal of Business and Society 14: 193-206.

Publisher's Note: MDPI stays neutral with regard to jurisdictional claims in published maps and institutional affiliations.

(C) 2020 by the authors. Licensee MDPI, Basel, Switzerland. This article is an open access article distributed under the terms and conditions of the Creative Commons Attribution (CC BY) license (http://creativecommons.org/licenses/by/4.0/). 